\title{
DESIGN AND ANALYSIS OF LOADER ATTACHMENT OF 13 TONNE EXCAVATOR FOR TUNNELING
}

\author{
SHIVASHANKAR. R, AURN C DIXIT, GURURAJA. S \& VISMAY. K G
}

Department of Mechanical Engineering, Vidyavardhaka College of Engineering, Mysuru, India

Excavators are heavy construction equipment consisting of a boom, arm, bucket and cabin on a rotating platform. All movement and functions of a hydraulic excavator are accomplished through the use of hydraulic fluid, with Hydraulic cylinders and Hydraulic motors. The excavator movement is actuated by an undercarriage with huge rubber tires or by means of a crawler track. In today's ever growing pace, construction operations, such as digging, ground leveling, carrying loads, dumping loads and straight traction play a very significant role and hydraulic excavators are needed to reduce manpower and complete the job in stipulated time more efficiently. Excavators provide solutions for handling materials within the confined areas of a tunnel. Purpose of tunneling may be for pedestrian walking, motor driving, rail travelling or even for making a path for water or oil transport through canal. In addition to this few tunnels are used for routing optic cables for signal transmission or cables for transmitting power or in some case used as sewers to transmit waste. The effective use of expensive construction machines has made it necessary to improve the performance characteristics of machines such as operating reach parameters and fault free operation within a tunnel. All these require for the study of the kinematics of the specified construction equipment. The project is carried out with respect to an existing 13 Ton class excavator manufactured by L\&T - KOMATSU Limited, Bangalore. The kinematics of the excavator needs to be altered suitably so that it can work within the tunnel of 5 meter dimension (customer requirement). The aim of the project is to study the kinematic reach and forces developed, create a conceptual design, modeling using CATIA and Pro/Engineer and the analysis of the design using ANSYS.

KEYWORDS: Loader Excavator, Tunneling, Vector Loop Method, Finite Element Analysis
\end{abstract}

Received: Jun 09, 2020; Accepted: Jun 29, 2020; Published: Aug 06, 2020; Paper Id.: IJMPERDJUN2020649

\section{INTRODUCTION}

Iron ore mining, coal mining, excavations, constructions of roads, tunneling etc. are all bits and pieces which play a prominent role in developing nations for economic growth. Improving infrastructures are of prominent value for any country. Usually hydraulic excavators are preferred for this purpose. The hydraulic excavators are the machines, which are powered by the hydraulic power for the earth excavation. The major components of a hydraulic excavator are the Boom, Arm, Bucket, the Hydraulic cylinders that deliver the forces for excavation purpose. These machines are well known for their mobility and are excellent machines for general-purpose work, such as digging trenches and pits. Due to hydraulic power these machines exert huge positive force that helps the bucket to penetrate the material to be excavated.

A tunneling operation involves only material handling process, a loader excavator is chosen as a loader can exert much higher thronging force and a higher capacity bucket can be used when compared to the class of back hoe excavator. The major advantage of the shovel to form its own path as it moves forwards makes it the most suitable 
excavator when digging above track level.

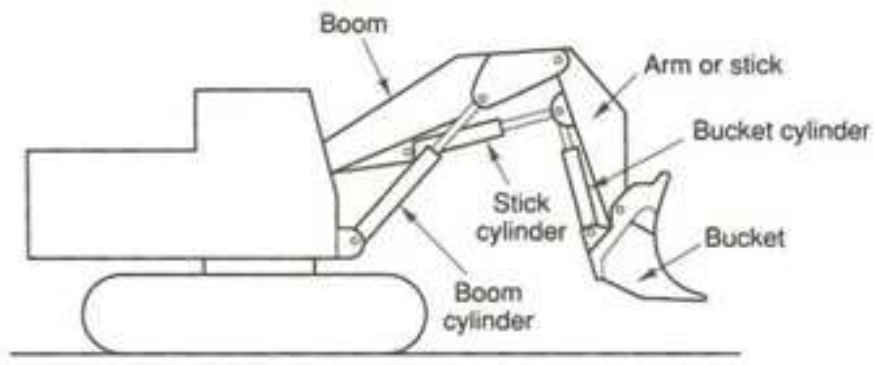

Figure 1: General View of Excavator.

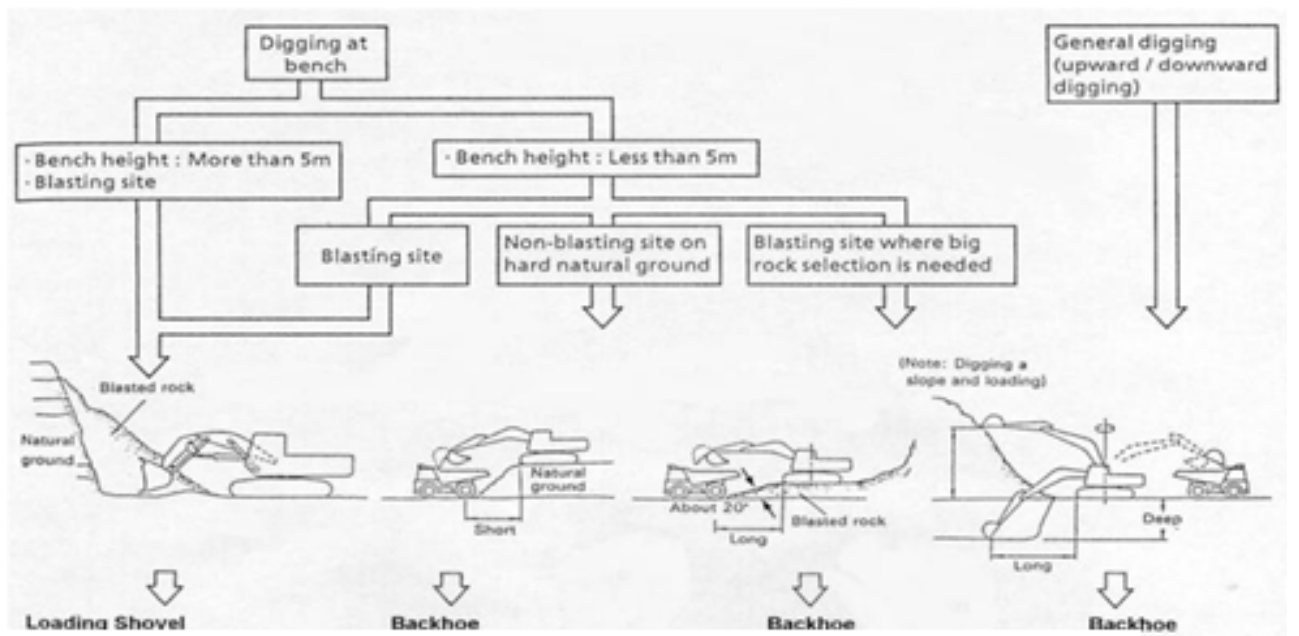

Figure 2: Selection of Excavator.

\section{KINEMATIC REACH AND FORCE ANALYSIS OF AN EXCAVATOR}

The excavator consists of three different independently controllable mechanisms, making it is a three-degree of freedom system. Boom cylinders are the actuators of first mechanism that is rotation of boom. The actuator thus forms an inverted slider-crank mechanism which is relative to the frame. The second mechanism is also an inverted slider crank which is used to rotate arm or dipper stick relative to boom. The last mechanism is for bucket rotation, as these buckets are large a combination of four-bar and inverted slider-crank mechanisms in series are used, to cause outward and backward motions during the excavation process.

The vector-loop method is a classical procedure that can give a set of solvable vector equations, which can be solved either graphically for the kinematics of a planar mechanism. Vector loops around the linkage can be created by a position vector in a mechanism. In a loop, the vectors in that loop take us from one link through a joint, to another link, and another joint, and so on until we return to the same link that we started from. Vector loops lead to algebraic equations that can be solved for the kinematics of a mechanism. In a sliding joint (the hydraulic cylinders) in a mechanism, we must define a variable-length vector along or parallel to the axis of the joint. The link configuration, proper length and excavator loader working space are adequately obtained by position analysis. 


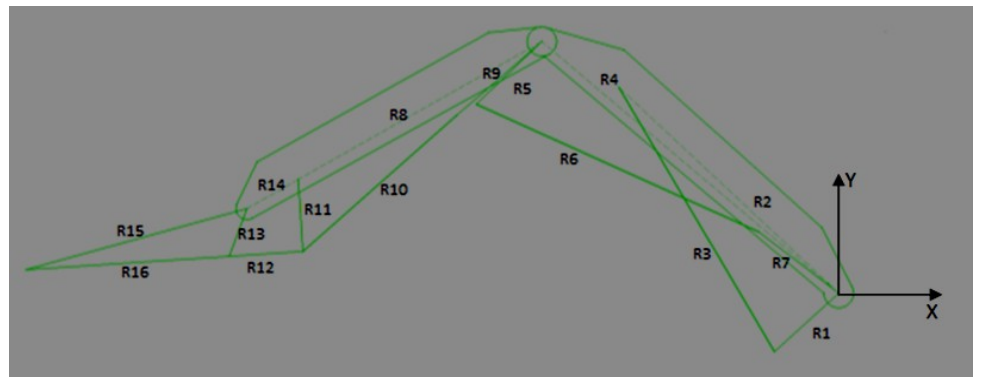

Figure 3: Free Body Diagram of Excavator.

The formulae mainly used to solve the vector loops are the distance formula and the cosine rule for finding out the angles. The pivot points of each point on the mechanism are known and distance formulae is applied as $R_{1}=\sqrt{\left(a_{x}^{2}-b_{x}\right)^{2}+\left(a_{y}^{2}-b_{y}\right)^{2}}$ and $R_{z}=\sqrt{\left(c_{-2}^{2}+5\right)^{2}}$

There are five vector loops that are formed. Each of the vector loops is solved and the resultant magnitude and angles are known. These vector loops leads to the formulation of the bucket tip co-ordinates given by

The values of these were incorporated in Microsoft Excel in order to deduce the various Reach Parameters of the excavator.

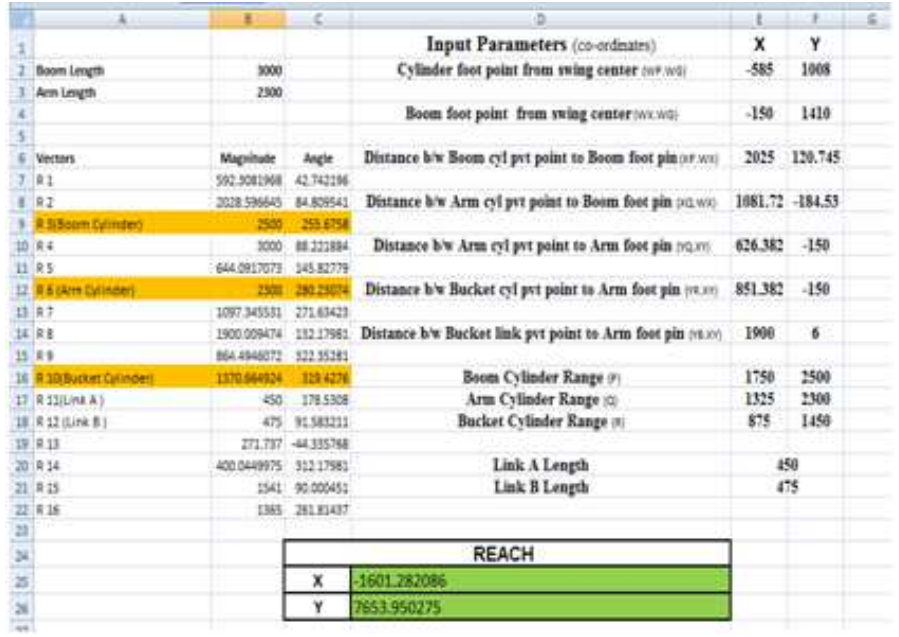

Figure 4: Pivot Points Calculation using Microsoft Excel.

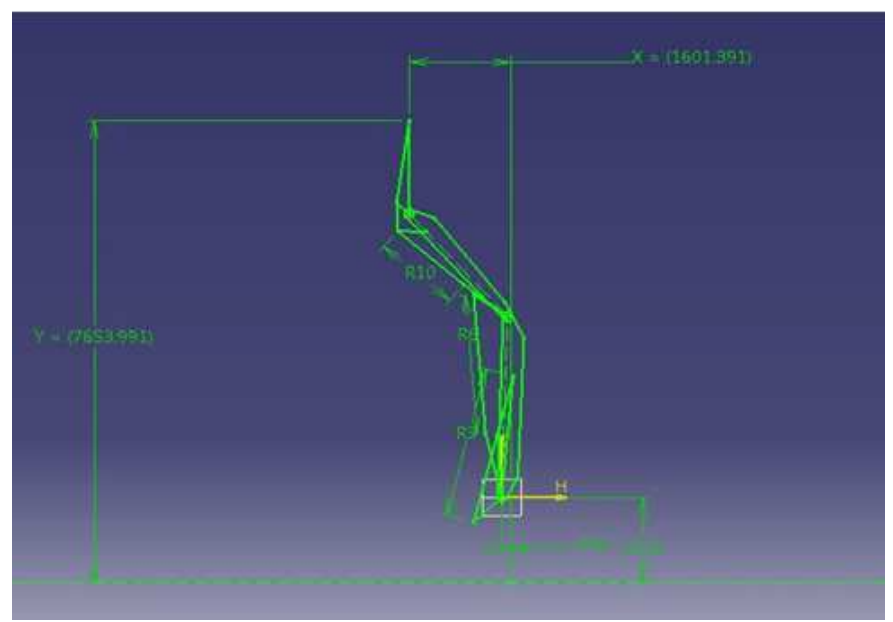

Figure 5: Graphical Co-Relation. 
To calculate reaction forces at various locations in an excavator during excavating process, a custom made program of L\&T-Komatsu that is GW basic program is used. The maximum bucket tangential force is the crowding force generated by the bucket cylinder and tangent to the arc of radius.

Table 1: Reach Parameters

\begin{tabular}{|c|c|}
\hline $\begin{array}{c}\text { Product (Boom\ Arm } \\
\text { Parameters Size) } \\
\end{array}$ & $\begin{array}{c}\text { 13Tonne Loader (Tunneling) } \\
(3.0 \mathrm{~m} / 2.3 \mathrm{~m})\end{array}$ \\
\hline Maximum Reach (A) & $6.6 \mathrm{~m}$ \\
\hline Maximum Cutting Height (B) & $7.6 \mathrm{~m}$ \\
\hline Maximum Digging Depth (C) & $2.07 \mathrm{~m}$ \\
\hline Maximum Dump Height (D) & $4.36 \mathrm{~m}$ \\
\hline Max Reach at Ground (E) & $6.28 \mathrm{~m}$ \\
\hline Reach at Cutting Height $(\mathrm{F})$ & $1.6 \mathrm{~m}$ \\
\hline Level Cut & $3.16 \mathrm{~m}$ \\
\hline Minimum Swing Radius & $1.98 \mathrm{~m}$ \\
\hline
\end{tabular}

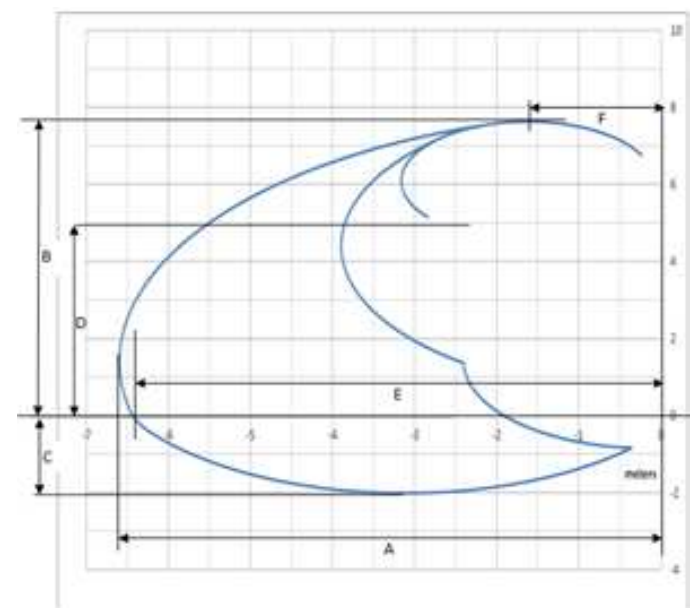

Figure 6: Envelope Diagram.

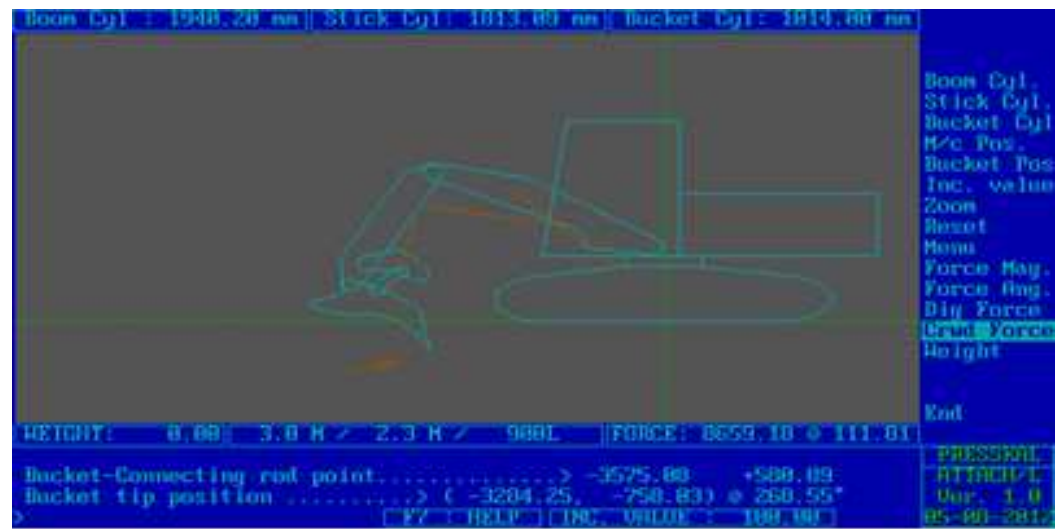

Figure 7: Force on Bucket Tip.

The crowding force obtained is $8659.18 \mathrm{~kg}\left(84.9 \mathrm{kN}\right.$ at $111.81^{\circ}$ with respect to front cutting edge of bucket tip. 


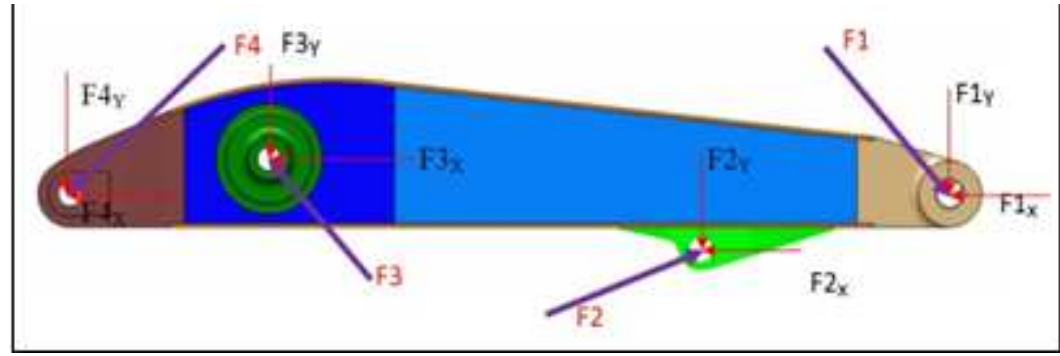

Figure 8: Forces Acting on Different points of Boom.

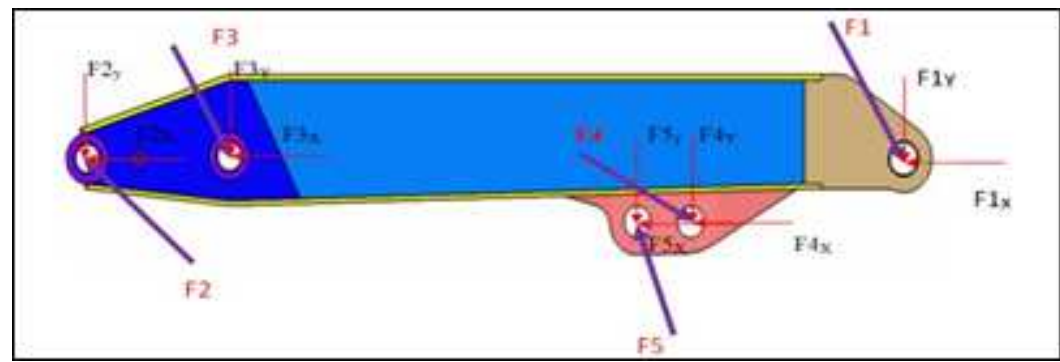

Figure 9: Forces Acting on Different Points of Arm.

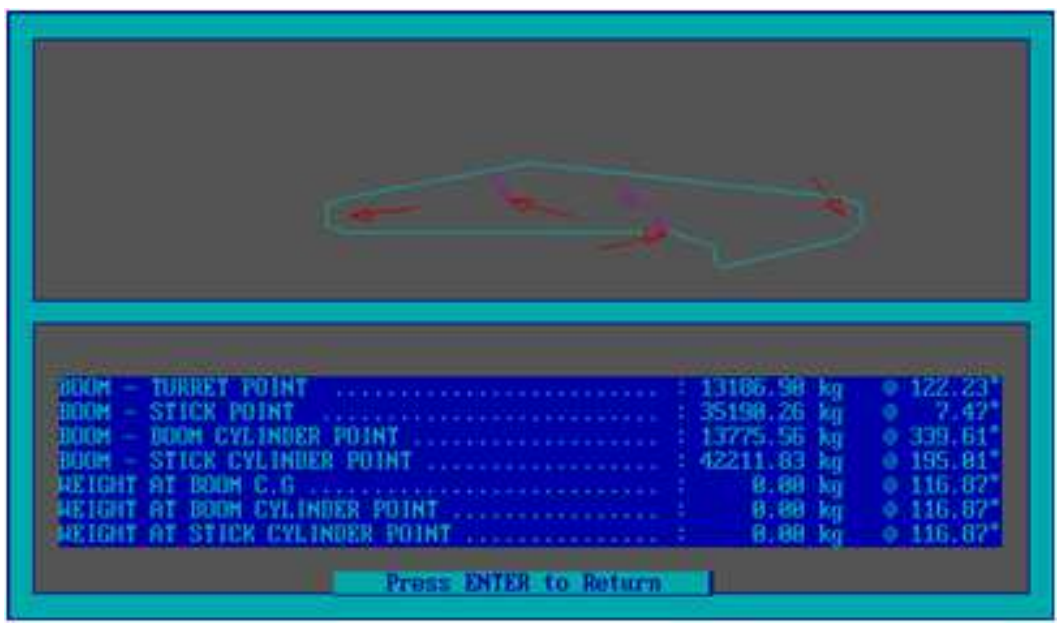

Figure 10: Forces at Different Locations on Arm.

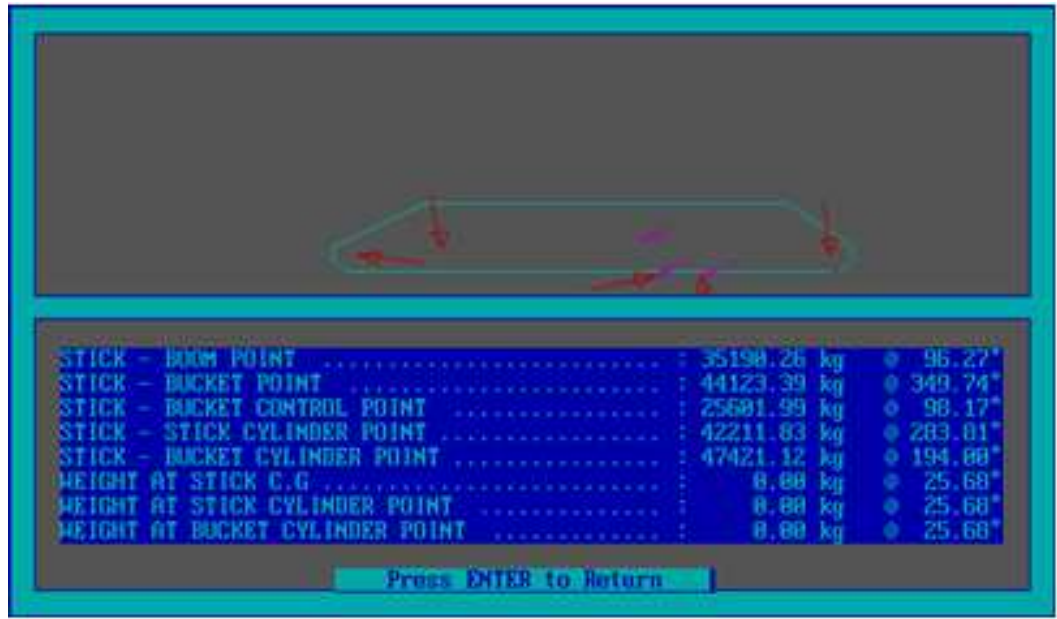

Figure 11: Forces at Different Locations on Arm. 
The Forces acting on each Point of the Boom and Arm are resolved into horizontal and vertical components. Using these forces the Axial force, Shear force, Bending moment, Minimum Sectional Area required and Minimum Section Modulus required at each locations are calculated. These values are used in designing of the Boom and Arm.

Table 2: AF, SF, BM, SA, SM for Boom

\begin{tabular}{|c|c|c|c|c|c|}
\hline Position & $\begin{array}{c}\text { Axial } \\
\text { Forces } \\
\mathrm{N}\end{array}$ & $\begin{array}{c}\text { Shear } \\
\text { Forces } \\
\mathrm{N}\end{array}$ & $\begin{array}{c}\text { Bending } \\
\text { Moment } \\
\text { N-mm }\end{array}$ & $\begin{array}{c}\text { Sectional } \\
\text { Area } \\
\text { Required } \\
\mathrm{mm}^{2}\end{array}$ & $\begin{array}{c}\text { Section } \\
\text { Modulus } \\
\text { Required }\end{array}$ \\
\hline $\begin{array}{c}\text { Arm } \\
\text { Boom } \\
\text { Point }\end{array}$ & 342286.6 & 44880.5 & 0 & 1836.40 & 0 \\
\hline $\begin{array}{c}\text { Boom } \\
\text { Cylinder } \\
\text { Point }\end{array}$ & 468957.4 & -2202.7 & $-2.85 \times 10^{\prime}$ & 2516.00 & $1.53 \times 10^{2}$ \\
\hline $\begin{array}{c}\text { Arm } \\
\text { Cylinder } \\
\text { Point }\end{array}$ & 68988.1 & -109449 & $3.50 \mathrm{X} 10^{7}$ & 370.12 & $1.88 \times 10^{2}$ \\
\hline $\begin{array}{c}\text { Turret } \\
\text { Point }\end{array}$ & -68992.0 & 109430 & 0 & 370.14 & 0 \\
\hline
\end{tabular}

Table 3: AF, SF, BM, SA, SM for Arm

\begin{tabular}{|c|c|c|c|c|c|}
\hline Position & $\begin{array}{c}\text { Axial } \\
\text { Forces } \\
\mathrm{N}\end{array}$ & $\begin{array}{c}\text { Shear } \\
\text { Forces } \\
\mathrm{N}\end{array}$ & $\begin{array}{c}\text { Bending } \\
\text { Moment } \\
\mathrm{N} \text {-mm }\end{array}$ & $\begin{array}{c}\text { Sectional } \\
\text { Area } \\
\text { Required } \\
\mathrm{mm}^{2}\end{array}$ & $\begin{array}{c}\text { Section } \\
\text { Modulus } \\
\text { Required }\end{array}$ \\
\hline $\begin{array}{c}\text { Arm- } \\
\text { Bucket } \\
\text { Point }\end{array}$ & 425929.01 & -77097.28 & 0 & 2285.14 & 0 \\
\hline $\begin{array}{c}\text { Linkage } \\
\text { Point }\end{array}$ & 390237.13 & 171509.20 & $3.25 \times 10^{\circ}$ & 2093.65 & $1.74 \times 10^{\circ}$ \\
\hline $\begin{array}{c}\text { Bucket } \\
\text { Cylinde } \\
\text { r Point }\end{array}$ & -61145.58 & 58966.85 & $-2.98 \times 10^{\circ}$ & 328.05 & $1.60 \times 10^{\circ}$ \\
\hline $\begin{array}{c}\text { Arm } \\
\text { Cylinde } \\
\text { r Point }\end{array}$ & 37700.83 & 343160.71 & $-2.54 \times 10^{\circ}$ & 202.26 & $1.36 \times 10^{\circ}$ \\
\hline $\begin{array}{c}\text { Boom- } \\
\text { Arm } \\
\text { Point }\end{array}$ & -37702.42 & 343151.46 & 0 & 202.27 & 0 \\
\hline
\end{tabular}

\section{DESIGN}

A detailed study was made on the previous models of the excavators to know the structural design of Boom and Arm for the best utilization of the existing components. Based on the conclusion from the detailed study the following designs of Boom and Arm are suggested. 


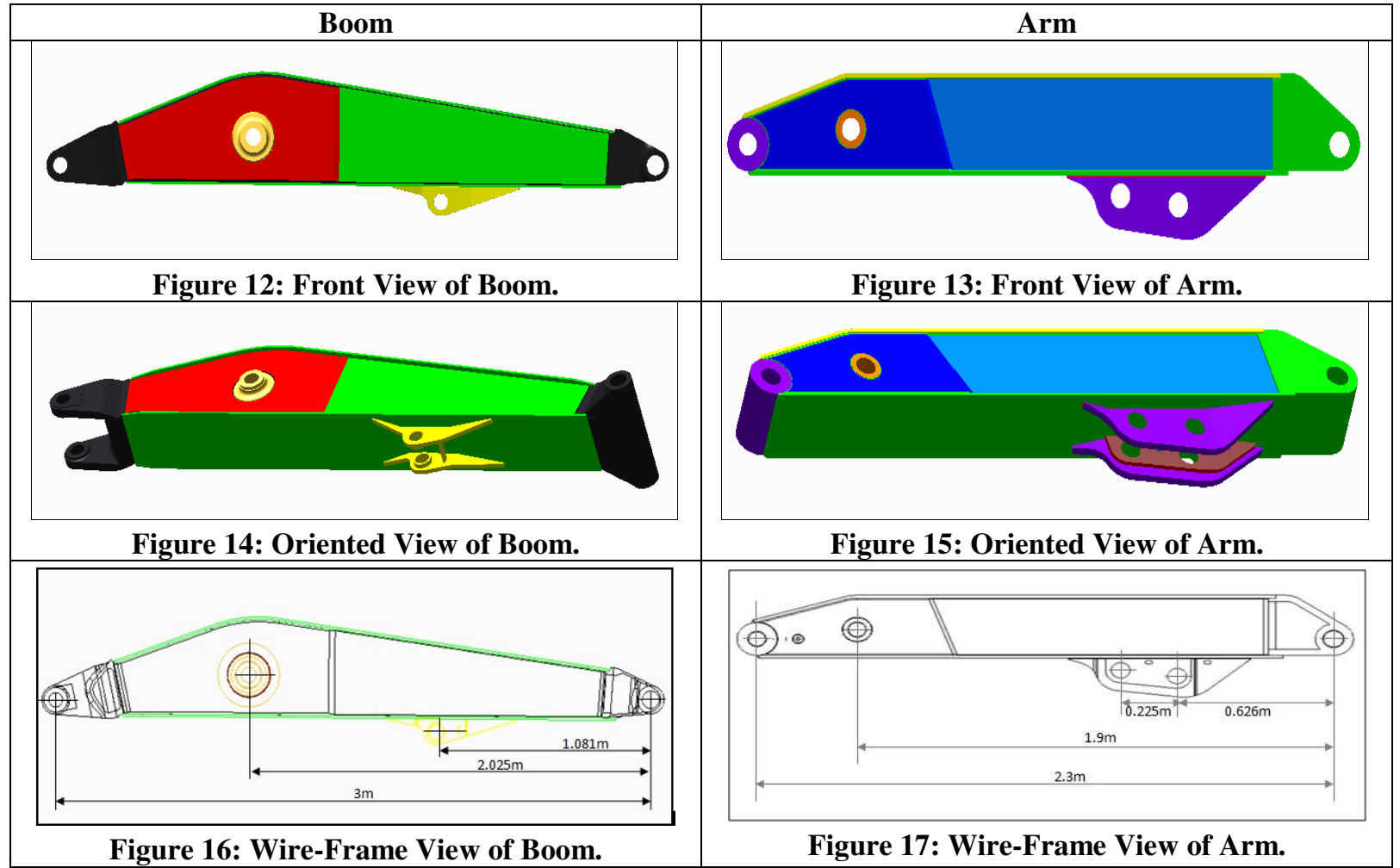

\section{ANALYSIS}

The continuity of the meshing is maintained even at the faces where the cross-sectional areas vary. This property of continuity has to be maintained throughout the volume and is an essential feature for accurate results. The pink colored area in the figure depicts the places where the coupling equations are used.

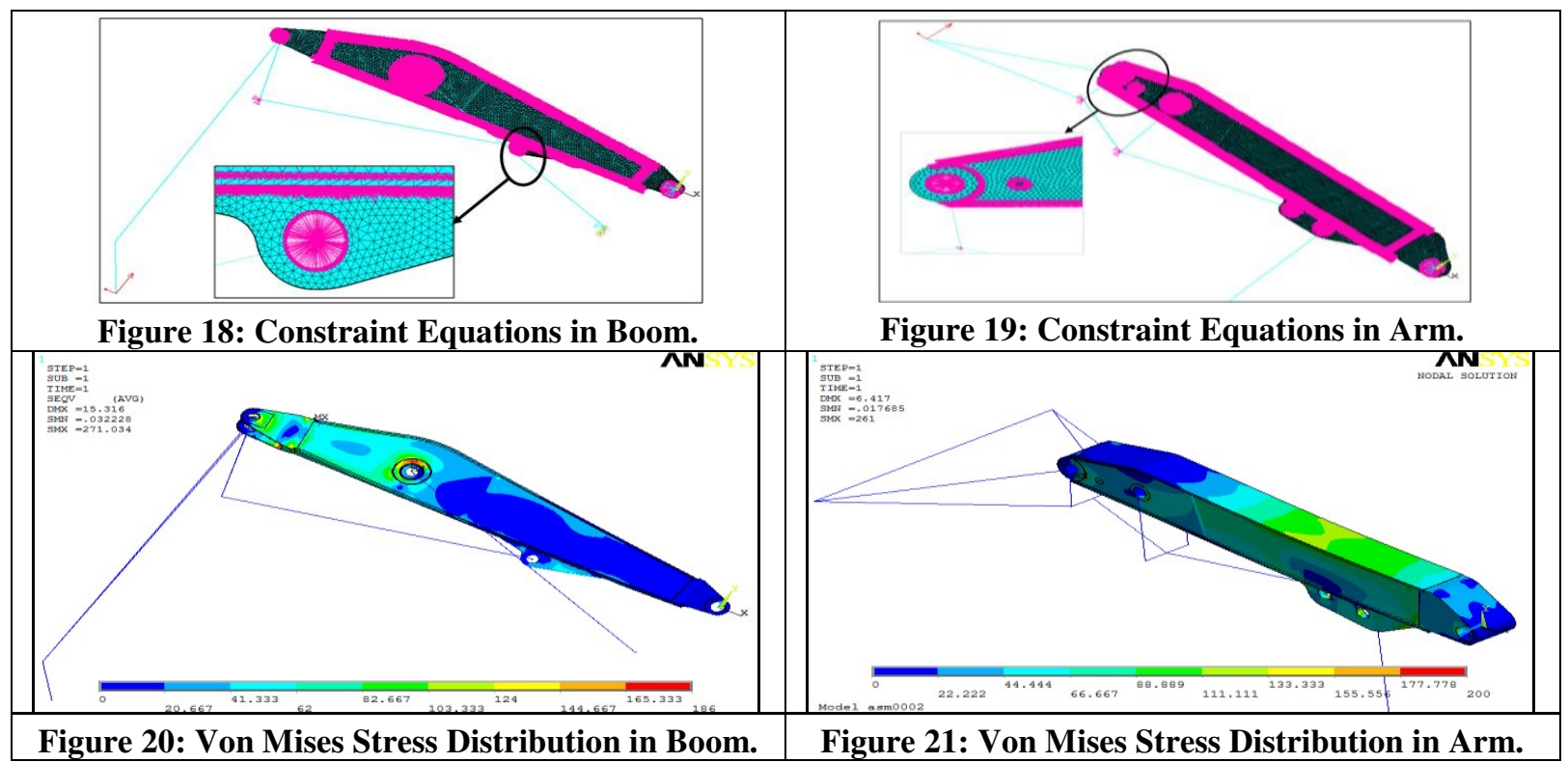




\section{CLOSURE}

This paper presents the Design and Analysis of Loader Excavator of 13 Tonne class. Kinematic reach analysis was done by Vector Loop Method. Microsoft Excel was used to optimize the Pivot Locations. A Boom length of 3.0m and Arm length of $2.3 \mathrm{~m}$ was found to be optimal for a tunnel size of $5 \mathrm{~m}$. Reach parameters of excavator for new attachments is found by using Microsoft Excel. Structure details were worked out through GW basic program, pressure in the cylinders and forces at various locations were estimated. The Boom was modeled using Pro/E Wildfire 5.0 and the Arm was modeled using CATIA V5 R18.

Ansys was used for analysis of stresses for critical loading condition. The maximum deflection encountered in the Boom was $1.844 \mathrm{~mm}$, while in the Arm it was $4.8 \mathrm{~mm}$, both of which were well within the safety limits of 6 to $7 \mathrm{~mm}$. The maximum Stress region in the Boom was found at the joint of the Arm Casting and Top Plate. The maximum value of which was $271 \mathrm{~N} / \mathrm{mm}^{2}$. In the Arm analysis, the maximum stress region was found at the joint of the Bucket Casting and Top Plate, at a value of $261 \mathrm{~N} / \mathrm{mm}^{2}$.

\section{REFERENCES}

1. Bhaveshkumar P Patel and Dr. J M Prajapati "A Review on Kinematics of Hydraulic Excavator's Backhoe Attachment”, International Journal of Engineering Science and Technology Vol. 3 No. 3 March2011.

2. Tiwari, B., and Uma Sharma. "Synthesis and Characterization of Titanium Metal Carbon Nano Tubes. "International Journal of Nanotechnology and Application (IJNA) 4. 2, Apr 2014, 15-20

3. Hsin-Sheng Lee, Shinn-Liang Chang and Kuo-Huang Lin, "A study of the design, manufacture and remote control of a pneumatic excavator”, International Journal of Mechanical Engineering Education,2002.

4. Phadke, Vaibhav, and Nikhil Titirmare. "Construction of Tunnels, by New Austrian Tunneling Method (NATM) and by Tunnel Boring Machine (TBM)." International Journal of Civil Engineering (IJCE) 6.6 (2017): 25-36.

5. Omar, Rodríguez P. "Uv radiation by the Debye sphere interaction plasma-metal nanoparticles on the surface of plant tissue." International Journal of Applied Engineering Research and Development (IJAERD) ISSN (P): 2250-1584.

6. Stephen H Gill, Harvey A Knell and Joseph M Tucker, "Shovel linkage for a hydraulic excavator", United States patent 4074820, 1978.

7. Chang, Chih-Yuan, et al. "Applying Strain-Sensing Technology for Monitoring and Diagnosing Peel-based Deterioration of Tiled Exterior Walls." Int. J. Civ. Struct. Environ. Infrastruct. Eng. Res. Dev 7 (2017): 39-48. 